Article

\title{
Overview of Polish Mining Wastes with Circular Economy Model and Its Comparison with Other Wastes
}

\author{
Justyna Woźniak *(1) and Katarzyna Pactwa \\ Faculty of Geoengineering, Mining and Geology, Industrial and GeoEconomics Division, Wroclaw University of \\ Science and Technology, Na Grobli 15, 50-421 Wroclaw, Poland; katarzyna.pactwa@pwr.edu.pl \\ * Correspondence: justyna.wozniak@pwr.edu.pl; Tel.: +48-71-320-6851
}

Received: 6 October 2018; Accepted: 30 October 2018; Published: 1 November 2018

check for updates

\begin{abstract}
This article discusses the main issues associated with waste from mining activity, which is the largest group of combined waste in Poland. A series of domestic and foreign solutions (practical and laboratory solutions) were indicated here, aimed at the management of waste in accordance with the tendency of circular economy (CE). In connection with the legislative changes, there is a need to resign from storage of the waste that is recyclable. The authors indicate mining waste as a potential for further studies, searching for solutions in regard to the use of waste as a raw material for sustainable, secondary use/reuse. Based on EUROSTAT data, the types of waste from mining and quarrying were grouped and the juxtaposition of all waste generated in Poland was implemented in the context of selected European economies. It was indicated which types of waste can be identified for reuse and management in accordance with CE. Rational management of mineral raw materials and therefore, maintaining of the level of extraction of domestic natural resources will contribute to maintaining not only energy independence, but also the leading position of Polish mining in the international aspect in the scope of extraction of metallic and rock raw materials. Mining waste can be and is reused in accordance with the concept of $\mathrm{CE}$, which was showed through the example of domestic industry enterprises and their business models.
\end{abstract}

Keywords: circular economy; mining waste; sustainability

\section{Introduction}

The circular economy (CE) has been a repeated concept in the context of European guidelines conducted scientific studies and attempts of their implementation [1-3]. The authors [4] of the review article undertook the task of analyzing 114 definitions of circular economy in order to ensure transparency in relation to the current understanding of the concept of circular economy. In this document, the most common concept of $\mathrm{CE}$ is the combination of reduction, reuse, recycling and recovery of materials in the processes of production, distribution and consumption, in accordance with widely understood sustainable development (taking care of the environment, society and economic development of current and future generations). Moreover, we read that defining of the CE concept is identified at 3 different levels that result from the scope of activities, i.e., macro (city, country and more), micro (among others: products, companies, consumers) and meso-understood as a regional level (e.g., eco-industrial parks) [4-7].

Mining is an industry for which the public opinion is often unfavorable. The reason for this is, among others, significant interference of the mining sector in the natural environment, as well as the scale of conducted activities. On the other hand, without access to various extracted raw materials, the infrastructural development in the micro- and macro-regional scale, from which we 
benefit every day (construction, road construction, power engineering, etc.), would not be possible. Unfavorable opinion concerning the mining industry and the lack of dissemination of knowledge regarding the benefits resulting from mining, which is a source of raw materials [8], makes it difficult to push through a positive approach to this industry. Recently, the right idea of municipal mines has been popularized [9], as well as recovery of rare earth elements (REE), and therefore, the limitation of traditional mining. Nevertheless, the market demand and maintaining the supply of natural raw materials will not completely exclude the traditional exploitation. The analysis of waste management in quantitative and qualitative terms can be conducive to change in the image of the discussed sector. This is especially important due to the fact that waste from mining and accompanying processes constitutes the largest group of industrial waste generated and stored in Poland, and in percentage terms it constitutes $42.3 \%$ of all waste $[10,11]$.

Due to the above, the purpose of this article is to present how Polish mining is struggling with various waste, how it identifies them and seeks solutions for their re-use in accordance with the concept of a circular economy. Extraction waste is created in a wide range of mining and associated activity, e.g., metal ore mining and accompanying processes, coal mining and energy production, rock raw material mining and processing.

In the laboratory conditions, the usefulness of fine-grained mining waste reinforced with cement was studied, among others, for the modernization of flood embankments [12], or the possibility of obtaining a mineral binder from flotation waste [13]. An interesting direction of using coal waste is its natural management in regard to the leveling of an area in biological reclamation [14]. Additionally, the solution described by [15] proposes converting post-production waste into useful products, e.g., sludge granulates, aggregates or aggregate-binder mixtures.

The implementation method of CE issues in mining was described, among others, by Lebre et al. (2017) [16], presenting the concept of reuse of waste from metallurgical processes, linking mining activity with water and waste management. Studies exist in the direction of reuse of mining waste in earthworks and construction, among others in asphalt surfaces [17], in the scope of manufacture of Portland cement [18] or geopolymers with the use of waste from the processing of copper and ashes with a high content of aluminum oxide and silica $[19,20]$. Moreover, studies conducted and described in the PhD thesis by the author of [21] confirm that mining waste (e.g., from rock mining) can find application in the architectural, technical-sculpting, construction, furniture and restaurant processes, through their reuse as composites with polymer mortars. Analysis of potential application of mining waste, conducted by the author of [22], indicates the possibilities of using waste from rock mining from the region of Lower Silesia, among others in the scope of fertilizing and improvement of soil, manufacture of sorbent fertilizers and light aggregates, in the scope of storage of fruits, vegetables or feed additives. An interesting direction for the use of post-production waste from the Portuguese (underground) tungsten mine, one of the largest in the world, is the development of innovative composite materials for technical and artistic applications. For example: sculpture and architecture, including, among others, as terrazzo tiles, or in the creation of urban furniture [23].

The use of the mining waste should follow the assessment of hazards that may result from the specificity of the waste and methods of dealing with it. This assessment is designed to assess the risk to human health and/or the environment, resulting from the generation and management of waste. For this purpose, the source-pathway-receptor model proposed by the authors of [24] can be used and implemented for the needs of the mining industry. This model should include information on: assessment of the source and properties of chemical substances present in waste, identification and confirmation of beneficial waste applications near the place of manufacture, defining the flow direction of the waste stream and exposure of objects (receptors) located on the transport route (e.g., dust), assessment of the impact of waste on the environment at the place of collection taking into account the pollution of the aquatic environment, land and atmospheric air.

Landfill disposal of large volumes of soft residues may also lead to geotechnical problems [25], including slope instability [26]. The slurry residue must be adequately dewatered at the municipal works 
by mechanical and/or thermal means and determined parameters in characterizing geoengineering behavior as the mass of the dry solids fraction (S.C.- - solid contents) expressed as a percentage of the bulk wet mass.

A common ground is important in the scope of promoting CE policy, associated with the business models of main waste producers, as well as the trust of social capital [27].

Due to the above, the purpose of this article is to present how Polish mining is struggling with various waste, how it identifies it and to what extent neutralizes it or whether it is transformed for reuse in accordance with the concept of circular economy.

\section{Materials and Methods}

The data analyzed in the article originate from several sources:

(1) from database of the statistical office of the European Union-EUROSTAT. The role of Eurostat changed and gained importance along with the development of Community policies. The main role of Eurostat is the processing and publication of comparable statistical information at the European level. Eurostat does not collect data. This is carried out in the Member States by their statistical authorities. They verify and analyze domestic data and send it to the Eurostat. Eurostat is engaged in data consolidation and ensures its comparability with the use of harmonized methodology. In reality, Eurostat is the only provider of statistics at the European level, while the published data is harmonized to the greatest possible extent [11]. The data used in the article represent the status as of the end of 2014,

(2) compilations of statistical data made available by statistical offices at the national level. In Poland, it is the Central Statistical Office, which is a government administration authority subordinate to the Prime Minister and dealing with the collection and sharing of statistical information. In Sweden, it is the Statistics Sweden (SCB), which is responsible for official statistics and other government statistics. It is engaged in the development, processing and dissemination of statistics,

(3) reports from integrated mining companies, which are prepared in accordance with the guidelines of the global standards of integrated reporting (GRI-Global Reporting Initiative). Non-financial data was analyzed. Reporting of non-financial data in domestic conditions is of particular importance, as in accordance with the Accounting Act of 15 December 2016, which implemented Directive 2014/95/EU [28], at the beginning of 2017 the presentation of non-financial data (E-Environment, S-Social, G-Governance) became an obligation of entities meeting the criteria of the number of employees (500 people for public interest entities under the Directive to expand non-financial information) and amounts balance sheet total (>EUR 20 million) or net income (>EUR 40 million), and this refers to the discussed companies as well. All of the above-mentioned data sets are generally available in the digital version.

(4) from the literature containing information about mining waste management in Poland.

The methods used were based on the analysis of available materials and the conclusion of a presentation.

\section{Results and Discussion}

At first, the analysis of data from Eurostat was analyzed. EUROSTAT [11] data is provided in two units, i.e., in total mass $(\mathrm{Mg})$ and unitary in $\mathrm{kg} /$ per capita. The legal basis in regard to the Community waste statistics is the Regulation of 2002 (EC) No. 2150/2002 [29]. In the scope of the European scale (EU-28), the construction sector generated the largest total amount of waste $34.7 \%$ (Table 1 ). The subsequent places were as follows: mining and quarrying $(28.2 \%)$, production $(10.2 \%)$, services in the scope of wastewater management $(9.1 \%)$ and households $(8.3 \%)$; the other $9.5 \%$ consisted of waste generated by other types of economic activity, mainly services (3.9\%) and energy sector (3.7\%). 
Table 1. Waste generation by economic activities and households—selected countries.

\begin{tabular}{cccccccc}
\hline & $\begin{array}{c}\text { Total } \\
\text { Waste }\end{array}$ & $\begin{array}{c}\text { Mining } \\
\text { and } \\
\text { Quarrying }\end{array}$ & Manufacturing & Energy & $\begin{array}{c}\text { Construction } \\
\text { and } \\
\text { Demolition }\end{array}$ & $\begin{array}{c}\text { Other } \\
\text { Economic } \\
\text { Activities }\end{array}$ & Households \\
\hline mln Mg & & & & $\%$ & & & \\
\hline EU-28 & 2502.9 & 28.1 & 10.2 & 3.7 & 34.7 & 14.9 & 8.3 \\
Romania & 175.6 & 87.0 & - & 4.0 & 0.6 & 6.2 & 2.2 \\
Bulgaria & 179.7 & 88.6 & - & 5.1 & 0.7 & 4.0 & 1.5 \\
Serbia & 49.1 & 84.5 & 1.8 & 9.1 & 0.6 & 0.7 & 3.3 \\
Sweden & 167.0 & 83.2 & 3.4 & 1.1 & 5.3 & 4.5 & 2.5 \\
Greece & 69.8 & 67.9 & 7.0 & 15.6 & 0.7 & 2.3 & 6.5 \\
Finland & 96.0 & 65.4 & 10.7 & 1.5 & 17.0 & 3.7 & 1.7 \\
Poland & 179.0 & 42.3 & 17.6 & 12.2 & 9.5 & 13.7 & 4.6 \\
Estonia & 21.8 & 36.3 & 20.2 & 32.6 & 3.1 & 5.6 & 2.2 \\
\hline
\end{tabular}

Source: EUROSTAT [11].

When juxtaposing Poland with other European countries (also those from outside the European Union) and considering the great importance of mining in the domestic economy, Poland is the leading European producer of mining waste. Taking into account the largest share of the produced amount of mining waste in the scope of total waste, the following countries are the leaders: Bulgaria, Romania; Serbia, Sweden, Greece and Finland, respectively. According to the MINE-GUIDE study covering EU countries "(https: / /www.min-guide.eu)", it was found that national mineral regulations do not sufficiently support innovative approaches and solutions. Many mining legislations mainly present a technical approach, focusing on technological and safety issues without establishing a framework for sustainability mining. There is a lack of qualitative national waste management policies developed by independent experts. The principle of sustainable development and good practice bases on the Social Corporate Responsibility should be included in the raw materials policy and waste management legislation. Poland takes first place with a $42.3 \%$ share of waste from the mining industry, at $28.1 \%$ for UE-28 (Table 1). The essence of a changeable approach to mining waste management should be emphasized. Each Member State has its own mining and related legislation, which mainly includes legislation on mineral waste. In some countries, mineral waste management is planned for each mining plant by a mining company, and is not obliged to report it to the waste management system (Eurostat). At this stage of the detail of the issue, it is difficult to verify, which is why it is used as a Mining Contribution Index (MCI) and mineral rents as a percentage of GDP (Table 2) [30].

Table 2. Share of mining: as a Mining Contribution Index (MCI) and mineral rents as a percentage of GDP—selected European countries.

\begin{tabular}{cccc}
\hline & Mineral Rent 2014 (as \% of GDP) & MCI Score 2014 & MCI Score 2016 \\
\hline Bulgaria & 1.48 & 61.84 & 63.2 \\
Serbia & 0.56 & 73.22 & 51.1 \\
Poland & 0.42 & 60.49 & 57.3 \\
Sweden & 0.37 & 59.11 & 58.8 \\
Finland & 0.32 & 55.29 & 61.5 \\
Greece & 0.13 & 48.27 & 57.6 \\
Romania & 0.03 & 42.28 & 33.2 \\
\hline
\end{tabular}

Source: own study based on ICMM [30].

Figure 1 shows the level of waste from the mining and quarrying sector among the countries for which the share of this waste is the highest in terms of percentage, i.e., $>30 \%$ in the total waste balance. The largest absolute value of mining and quarrying waste is generated in Bulgaria, Romania, Sweden and Poland. Considering the relation of the level of mining waste to the number of inhabitants, Poland with a result of $1992 \mathrm{~kg} /$ per capita looks more favorable in this juxtaposition (Figure 1). Apart from the aforementioned countries, i.e., Bulgaria, Romania, Serbia, Sweden and Finland, also 
larger number of mining waste per capita than Poland is generated by Estonia $6013 \mathrm{~kg} /$ per capita and Greece $4348 \mathrm{~kg} /$ per capita. Of course, due to the leading position of mining in the domestic economy, Poland is among countries with a high share of mining waste, which should be perceived as a research field in the direction of reuse and processing of this waste as raw materials, in accordance with CE.

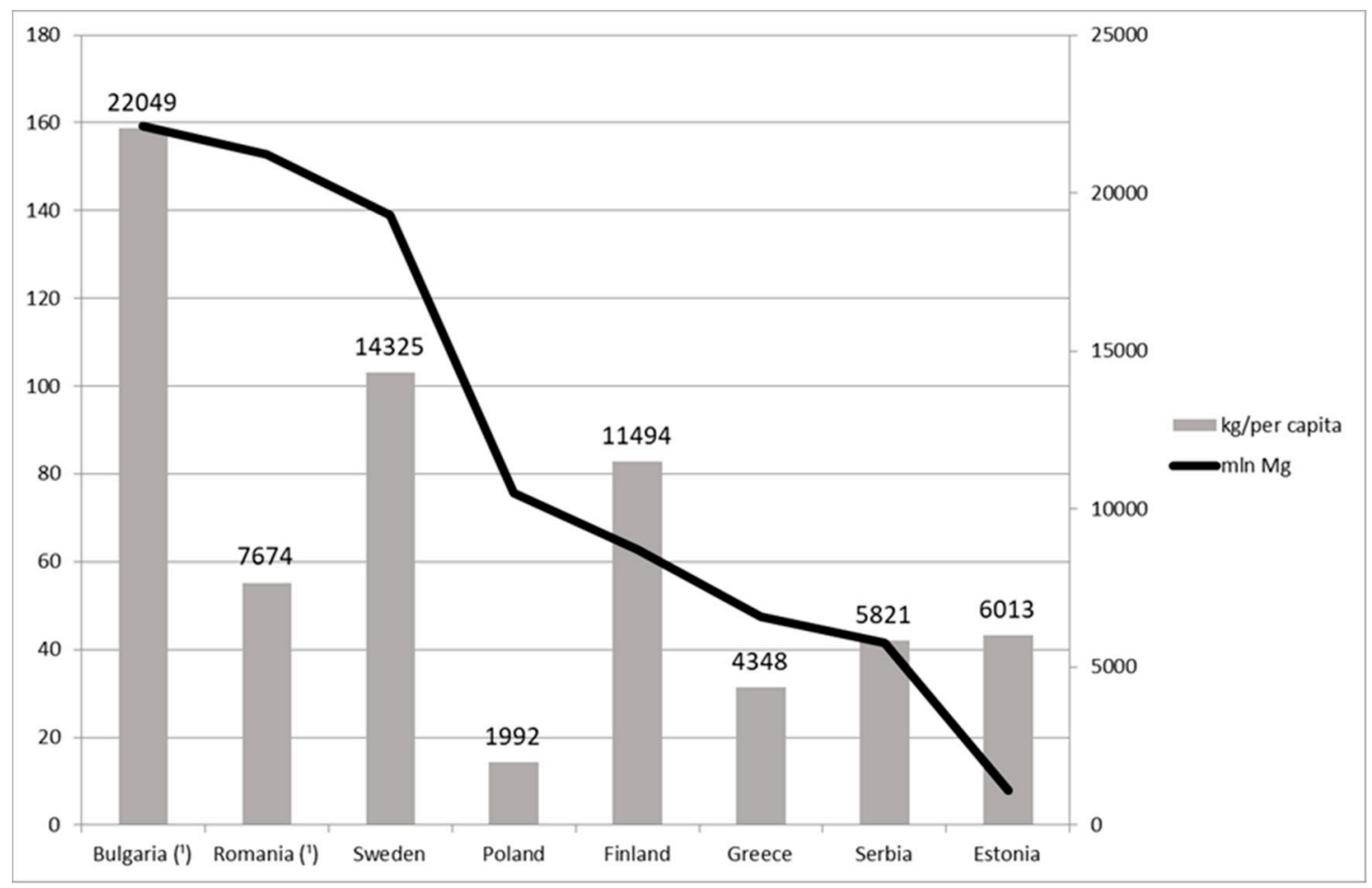

Figure 1. Waste from mining and quarrying—selected European countries (source: own study based on EUROSTAT [11]). $\left({ }^{1}\right)$ Other types of activity including production.

Mineral rents are defined as production values minus 'normal costs' (Table 2). So they loosely approximate to the aggregation of tax and profit above 'normal' profits from mining (The World Bank publishes estimates of natural resource rents as a percentage of GDP for minerals and coal separately. It defines these rents as the production values of a range of minerals less their "normal" costs of production including an appropriate rate of return on investment. Their addition to the MCI does add new information relative to the existing production value indicator). Therefore, the new indicator may have a relatively small numerical value but may also be quite volatile to changing circumstances such as downswings in mineral prices. The $\mathrm{MCI}$ aims to synthesize into a single number-and an associated ranking-the significance of the mining sector's contribution to national economies. The MCI is comprised of four indicators, each capturing different aspects of mining's contribution to national economies: mineral and metal export contribution, increase/decrease in mineral and metal export contribution (last 5 years), mineral production value expressed as a percentage of GDP and mineral rents as a percentage of GDP. Comparing the mining waste list in Figure 1 (8 countries) to the content in Table 2, Estonia has not been intentionally included in it, whose share of mineral rent as\% of GDP was at zero to indicate different classifications in each country.

The main direction of waste processing in the EU-28 (47.4\%) is the disposal of waste through their storage (Table 3) -in Poland it is $24.9 \%$. Another $36.2 \%$ of waste processed in the EU-28 was intended for recovery other than energy recovery and filling up excavations (recycling for simplification) - in Poland $50.5 \%$. The presented data regarding such a high level of recycling results in uncertainty and is subject to error due to manual records of waste in some Polish local government units, as well as a general/impractical manner of estimating these values [31]. In the case of comparing the level of recycling in Swedish waste management 9.3\%, the level of 50.5\% for Poland is unattainable. 
Approx. $10.2 \%$ of European waste is intended for deposits in excavations, while the remaining part is burned for energy recovery $(4.7 \%)$ or without such an intended use (1.5\%). Poland burns waste and obtains energy in this process in the small percentage of $2.7 \%$, with a negligible direction of waste incineration of $0.4 \%$. During analysis of waste processing in individual countries, there's a visible discrepancy in the used methods.

Table 3. Waste treatment in European Union (EU), 2014.

\begin{tabular}{|c|c|c|c|c|c|c|}
\hline & $\begin{array}{c}\text { Total } \\
\text { Waste }\end{array}$ & Landfill & Incineration & Energy Recovery & Backfilling & Recycling \\
\hline $\mathrm{mln} \mathrm{Mg}$ & & & & $\%$ & & \\
\hline EU-28 & 2319.5 & 47.4 & 1.5 & 4.7 & 10.2 & 36.2 \\
\hline Belgium & 42.8 & 8.2 & 4.3 & 13.6 & 0.0 & 73.9 \\
\hline Bulgaria & 175.7 & 97.9 & 0.0 & 0.1 & 0.0 & 2.0 \\
\hline Czech Republic & 19.9 & 17.3 & 0.4 & 5.1 & 29.1 & 48.1 \\
\hline Denmark & 17.7 & 21.7 & 0.0 & 20.7 & 0.0 & 57.6 \\
\hline Germany & 370.7 & 19.2 & 2.3 & 10.5 & 25.3 & 42.7 \\
\hline Estonia & 20.7 & 65.6 & 0.0 & 2.5 & 11.9 & 20.0 \\
\hline Ireland & 10.0 & 42.6 & 0.1 & 7.2 & 37.4 & 12.7 \\
\hline Greece & 67.1 & 88.4 & 0.0 & 0.2 & 8.1 & 3.2 \\
\hline Spain & 103.4 & 47.9 & 0.0 & 3.4 & 12.6 & 36.1 \\
\hline France & 299.7 & 29.3 & 2.0 & 4.5 & 10.7 & 53.6 \\
\hline Croatia & 3.5 & 51.1 & 0.0 & 1.4 & 2.0 & 45.5 \\
\hline Italy & 129.2 & 16.0 & 5.2 & 1.6 & 0.2 & 76.9 \\
\hline Cyprus & 1.8 & 58.9 & 0.0 & 1.7 & 25.9 & 13.5 \\
\hline Latvia & 1.9 & 34.8 & 0.0 & 8.7 & 0.9 & 55.5 \\
\hline Lithuania & 4.5 & 67.6 & 0.1 & 4.1 & 2.5 & 25.8 \\
\hline Luxembourg & 8.5 & 38.3 & 0.0 & 2.5 & 16.0 & 43.3 \\
\hline Hungary & 13.7 & 39.4 & 0.7 & 8.9 & 3.7 & 47.3 \\
\hline Malta & 1.6 & 28.9 & 0.4 & 0.0 & 37.5 & 33.3 \\
\hline Netherlands & 130.6 & 45.4 & 1.0 & 7.9 & 0.0 & 45.7 \\
\hline Austria & 53.9 & 38.6 & 0.2 & 6.5 & 20.1 & 34.7 \\
\hline$\underline{\text { Poland }}$ & $\underline{182.4}$ & $\underline{24.9}$ & $\underline{0.4}$ & $\underline{2.7}$ & $\underline{21.5}$ & $\underline{50.5}$ \\
\hline$\overline{\text { Portugal }}$ & 9.9 & $\overline{31.8}$ & $\overline{10.0}$ & $\overline{3.1}$ & $\overline{0.0}$ & $\overline{55.0}$ \\
\hline Romania & 172.2 & 94.4 & 0.0 & 1.3 & 0.6 & 3.7 \\
\hline Slovenia & 5.4 & 9.2 & 0.6 & 4.9 & 33.5 & 51.8 \\
\hline Slovakia & 7.1 & 53.8 & 0.8 & 4.4 & 0.0 & 40.9 \\
\hline Finland & 93.3 & 80.9 & 0.5 & 4.8 & 0.0 & 13.8 \\
\hline Sweden & 163.3 & 84.4 & 0.1 & 4.7 & 1.6 & 9.3 \\
\hline United Kingdom & 209.0 & 41.5 & 3.6 & 0.9 & 10.4 & 43.6 \\
\hline Iceland $\left({ }^{1}\right)$ & 0.5 & 30.7 & 0.0 & 2.7 & 0.6 & 66.0 \\
\hline Norway & 11.7 & 17.9 & 0.5 & 35.8 & 5.3 & 40.5 \\
\hline Montenegro & 1.0 & 98.8 & 0.0 & 0.1 & 0.0 & 1.0 \\
\hline FYR of Macedonia & 1.5 & 98.7 & 1.3 & 0.0 & 0.0 & 0.0 \\
\hline Albania & 1.2 & 74.8 & 3.1 & 0.5 & 0.0 & 21.6 \\
\hline Serbia & 49.4 & 97.3 & 0.0 & 0.1 & 0.0 & 2.6 \\
\hline Turkey & 79.3 & 70.2 & 0.0 & 0.7 & $:$ & 29.0 \\
\hline
\end{tabular}

Source: EUROSTAT [11]. $\left({ }^{1}\right)$-data from 2012.

In order to achieve detailed presentation and interpretation of waste management in Poland, the state policy was compared to a developed country-Sweden. Sweden has been an EU member since 1995, and its waste management system is assessed as one of the better [32]. Less than $1 \%$ of municipal waste goes to landfills [33]. The issues of waste management in Sweden have been presented and analysed for many years (among others by [34]). The first (the most important) step in the approach to waste management is prevention of their creation. This is a priority for Swedish legislation, but also for European legislation. Subsequent solutions include reuse, recycling of materials, biological processing and the remaining solutions in the scope of recycling, e.g., energy recovery and disposal (through storage). It should be considered that the presented classification in waste management can be subject to change due to technical, financial or environmental reasons. According to Avfall Sverige (Swedish Waste Management) [35], commercial association of communes in the scope of 
waste management and recycling, over the last 40 years, Swedes gradually reduced the amount of waste stored on landfills, while simultaneously increased their use for energy production (both electricity and heat) and recycling. And although the Swedish management of municipal waste is undoubtedly a model to follow, the industrial waste, including waste from the mining and quarrying industry, constituting a significant share (mining and quarrying in 2014 constituted the source of over 138 million $\mathrm{Mg}$, while in 2016, 109 million $\mathrm{Mg}$ of non-hazardous waste, as well as $6000 \mathrm{Mg}$ and $9000 \mathrm{Mg}$ of hazardous waste (source: [36] in total waste, are a challenge within the understanding of waste management with the use of a five-point scale (Reduce, Reuse, Recycle, Recovery, Landfill) and circular economy. The authors of Quality Report on Waste Statistics 2014 generation of waste and recovery and disposal of waste according to EU Regulation on Waste Statistics Sweden [37] indicate that the main method of dealing with mining waste is their storage on the surface, classified as "other disposal", selected waste is used to fill excavations, as well as to build roads at the place of extraction. The issues associated with the industrial waste are discussed by (among others) Johansson and Corvellec [38]. Taking into account that Swedish national and local plans focus on small waste streams such as food waste and not on larger ones such as industrial and commercial waste, identification of the problem in a country that has been developing waste management according to circular economy for several decades, allows to think that it is a challenge and its solution constitutes a global problem.

\subsection{Mining Waste—National Dimension (Poland)}

The legal provision constituting the legal basis for management of mining waste in Poland is Dz.U.2017.1849 [39], which also includes references to the provisions of geological and mining law, environmental protection, protection of agricultural and forest land, water law or nature protection. The main rules for management of mining waste (classified as hazardous and non-hazardous, excluding overburden layers-identified as a positive manifestation of the opencast activity [40] are based on limiting the generation of mining waste and minimizing their impact on the environment. First, the legislator imposes recovery obligation on the producer of mining waste, and in the case when it is impossible, e.g., due to technological or economic reasons, it is obliged to dispose it in the nearest places.

In 2016, according to the data of the Central Statistical Office (CSO pl.GUS), 140 million Mg of waste was generated in Poland, out of which $52 \%$ constituted waste from the mining and quarrying industry, $21 \%$ from industrial processing and $16 \%$ from generation and provision of electricity [41]. The trend of leading role of the mining industry in the amount of waste generated in the country has been maintained for several years. In 2016, approximately 56\% constituted waste generated during the exploration, extraction, physical and chemical processing of ores and other minerals $(22 \%$ waste from thermal processes).

Waste associated with the domestic mining industry, in the total amount of 128,307 million $\mathrm{Mg}$, were produced according to the types:

- $25.0 \%$, waste generated at washing and cleaning minerals,

- $24.3 \%$, waste from floatation dressing of nonferrous metal ores,

- $24.0 \%$, other,

- $8.9 \%$, dust-slag compounds from wet treatment of furnace waste,

- $5.8 \%$, soil and stones,

- $4.9 \%$, waste from mineral non-metalliferous excavation,

- $2.5 \%$, coal fly ash,

- $2.5 \%$, wastes from the processing of slag,

- $2.3 \%$ dust-slag compounds from wet treatment of furnace waste.

Out of the total amount of waste generated in 2016, $49.5 \%$ of waste was recovered, $42 \%$ was disposed of by storage and $4 \%$ was disposed in other manner, specifying [41]:

- waste generated at washing rinsing and cleaning of minerals $32 \mathrm{mln} \mathrm{Mg}$, subject to recovery in $75.7 \%$, disposed by storage $23.1 \%$, stored temporarily $1.3 \%$, 
- waste from floatation dressing of nonferrous metal ores $31.2 \mathrm{mln} \mathrm{Mg}$, subject to recovery in $4.2 \%$, disposed by storage $95.8 \%$,

- dust-slag compounds from wet treatment of furnace waste $11.4 \mathrm{mln} \mathrm{Mg}$, subject to recovery in $8.6 \%$, disposed by storage $86.5 \%$, stored temporarily $0.9 \%$,

- soil, including stones $7.4 \mathrm{mln} \mathrm{Mg}$, subject to recovery in $70.5 \%$, disposed by storage $3.0 \%$, stored temporarily $0.4 \%$,

- waste from mineral non-metalliferous excavation $6.2 \mathrm{mln} \mathrm{Mg}$, subject to recovery in $45.6 \%$, disposed by storage $51.9 \%$, not stored temporarily,

- coal fly ash $3.3 \mathrm{mln} \mathrm{Mg}$, subject to recovery in $86.7 \%$, disposed and not stored $11.3 \%$, stored temporarily $2.0 \%$,

- wastes from the processing of slag $3.2 \mathrm{mln} \mathrm{Mg}$, subject to recovery in $99.2 \%$, disposed and not stored $0.4 \%$, stored temporarily $0.4 \%$,

- dust-slag compounds from wet treatment of furnace waste $3 \mathrm{mln} \mathrm{Mg}$, subject to recovery in $92.8 \%$, disposed and not stored $0.1 \%$, stored temporarily $0.5 \%$.

Wastes arising from the operation and processing of copper ores are the first to be discussed. The first group-mining waste-is created during the access, preparatory and operational works, mainly copper-bearing shales, sandstones, limestones and dolomites. The second group is flotation wastes (processing), constituting over $90 \%$ by weight of the extracted ore. The nature of waste is determined by the components found in them in the largest amounts, i.e., sandstones and carbonate rocks (dolomites and limestones), as well as marls and clay rocks. Gangue from historical mining operations was deposited in the areas of former copper deposits exploitation. Currently, it is used for road hardening or is located in mines' goafs. Since 1953, post-flotation landfills were filled with processing wastes. On one of the landfills, in 1967, the embankment was interrupted, accompanied by a rapid outflow of water with sediments. The valley of the Bobrzyca river and several villages were flooded. 18 people died. Objects the disposal of mining waste from the treatment of copper ore are characterized by a nuisance to the environment by: polluting groundwater, soil and soils as a result of infiltration of supernatant waters into the ground, air pollution with dust or flooding of adjacent areas due to rising groundwater level [42]. Research is being carried out to minimize the negative impact, e.g., by using a mechanical bitumen layer to protect against dusting [43].

Work on the economic use of flotation waste, which is one of the leading groups of mining waste (for 2016 it was $29.9 \mathrm{mln} \mathrm{Mg}$ disposed by storage) in Poland was included in the article [44]. It has been found that as a result of the thermal treatment of a suitably selected material with a high carbonate content, it is possible to obtain a material having binding properties. Mining wastes in KGHM-Kombinat Górniczo-Hutniczy Miedzi Polska Miedź S.A. arise in the process of flotation of copper ore, they are mineral wastes (highly disintegrated gangue), neutral to the environment, harmless to health. The chemical and mineral composition depends on the type of ore. In the case of sandstone ore, quartz is predominant $-44.4 \%$, and in a smaller amount there are carbonate minerals, such as: dolomite- $29.9 \%$ and calcite- $-7.7 \%$. Sandstone waste contains about $50 \% \mathrm{SiO}_{2}, 13 \% \mathrm{CaO}$ and $5 \% \mathrm{MgO}$. The finely divided carbonate waste has about $24 \% \mathrm{CaO}, 20 \% \mathrm{SiO}_{2}$ and more than $5 \% \mathrm{MgO}$, and these are the most useful for obtaining a binder characterized by binding properties (containing significant amounts of the carbonate component). On the basis of tests using thermal differential analysis, it was found that the decomposition process of magnesium carbonate and calcium carbonate occurs at a temperature of $700-850{ }^{\circ} \mathrm{C}$ (loss of roasting of about $26 \%$ ). Carbonate waste is rich in calcite, dolomite and quartz, and there is illit and bassanit which can be used for the production of road binders, binders for solidifying backfilling materials and stabilization and as a material containing active calcium and magnesium oxides for environmental protection purposes, for example for flue gas desulfurization and hygiene of sewage sludge [44,45]. 
When considering issues related to mining waste, one cannot fail to mention waste in hard coal mining. Minerals, which together with lignite provides Poland with a high degree of energy independence. Although in the last few years the share of electricity produced from hard coal in the overall balance has decreased, it can still be considered significant $(79,400 \mathrm{GWh}$ of electricity in 2016, which constitutes $47.6 \%$ of the total share). It is a fuel used also for the production of thermal energy [46]. Waste in hard coal mining are rocks from mining and preparatory works. It comes from the floor, roof and overgrown of coal seams, which during the exploitation pass into the spoil, and then in the enrichment processes are separated from the coal. We distinguish among them non-selective mining rocks, they are coarse waste (about $20 \%$ of the total weight) and processing waste, which can be divided depending on the technology used for waste from manual enrichment, from gravity enrichment, from centrifugal enrichment, from flotation [42]. Waste from hard coal mining is widely used. It is managed using, among others, for filling excavations, leveling land, engineering works. Unfortunately, in the past, the majority of the mining waste was located on the dumping grounds. At these objects, so far, rock waste accumulated mainly in the course of sharing coal seams, its exploitation and enrichment processes. There are flammable components: coal and pyrite, which in contact with oxygen can become spontaneous. In this way, fires may occur, the emergence of which depends on internal factors (including the properties of waste material, oxygen access, preventing heat dissipation) and external fires (outbreaks, burning of grasses). These fires pose a threat both as a source of emission of harmful substances into the atmosphere $\left(\mathrm{CO}, \mathrm{SO}_{2}\right.$ or $\left.\mathrm{NO}_{\mathrm{x}}\right)$ and are dangerous for people in the dump. To reduce the likelihood of a fire, it is possible to mix the flammable material with another non-combustible material or to use anti-pyrogens that reduce its chemical activity (e.g., $\mathrm{Ca}(\mathrm{OH})_{2}$, $\mathrm{CaCO}_{3}, \mathrm{CaCl}_{2}$ ). The main element of fire prevention is the significant limitation of air access to the interior of the repository. It is also advisable to look for opportunities, according to $\mathrm{CE}$, for the economic use of the deposited material [47]. Forecasting of the fire hazard of post-mining waste is being carried out. The methods used are subject to modification. The proposed changes concern permanent thermal monitoring of the facility, assessment of embankment parameters, density of individual fragments of landfills [48].

The other waste $(24 \%)$ is not identified in detail. It may include, e.g., belts from continuous transport, i.e., from belt conveyors with steel cables, installed among others in open-cast mines that were previously stored in the overburden. In the context of applicable regulations, the records of used belts with steel core structure becomes problematic and the method of their reuse or environmentally friendly utilization is sought. A part of the "belt waste" is used on the spot as fenders or reinforcements, other part is sold to smaller rock mines. Their structure creates a problem in the extraction of cables from the inside of a rubber belt. Recent research works confirm the savings in the scope of reduction of waste from belt conveyors through the use of the diagnostic system DiagBelt [49]. The variant of belt regeneration (single or double) is also emphasized as a manifestation of circular economy and a manner to minimize waste that previously was stored. In the domestic hard coal mining, worn out belts with textile core are usually sold as a high energy product.

Mining waste generated in a given year is not the only existing waste. The industry is also struggling with waste accumulated during the previous years (on landfills) as a result of operating activity of enterprises. As of the end of 2016, the amount of waste generated in relation to the accumulated amounted to $7.5 \%$. The type classification of stored waste $(1,710,646$ million $\mathrm{Mg})$ is presented below:

- $25.7 \%$ waste generated at washing and cleaning minerals,

- $37 \%$ waste from floatation dressing of nonferrous metal ores,

- $13.1 \%$ other,

- $17.7 \%$, dust-slag compounds from wet treatment of furnace waste,

- $0.02 \%$ soil and stones,

- $4.7 \%$ waste from mineral non-metalliferrous excavation, 
- $1.5 \%$ coal fly ash,

- $0.14 \%$ wastes from the processing of slag,

- $0 \%$ dust-slag compounds from wet treatment of furnace waste.

\subsection{Waste Generated as a Result of the Activity of Selected Mining Companies}

During the next stage of studies, the statistics of mining waste generated by three domestic companies were compared:

- KGHM Polska Miedź S.A. engaged in the extraction and processing of copper,

- PGE Górnictwo i Energetyka Konwencjonalna-a member of the PGE Capital Group (Polska Grupa Energetyczna), a leader in the sector of brown coal mining with the use of opencast method,

- JSW Jastrzębska Spółka Węglowa S.A.-the largest producer of high-quality hard coking coal and a significant producer of coke in the European Union.

The weight of hazardous and non-hazardous waste was analyzed. Values presented in Figure 2 are absolute values expressed in million Mg, for KGHM, PGE (GiEK) and JSW, respectively. The data comes from the latest integrated reports of the above-mentioned companies and concerns the activity in the last two years [50-52].

[mln Mg]

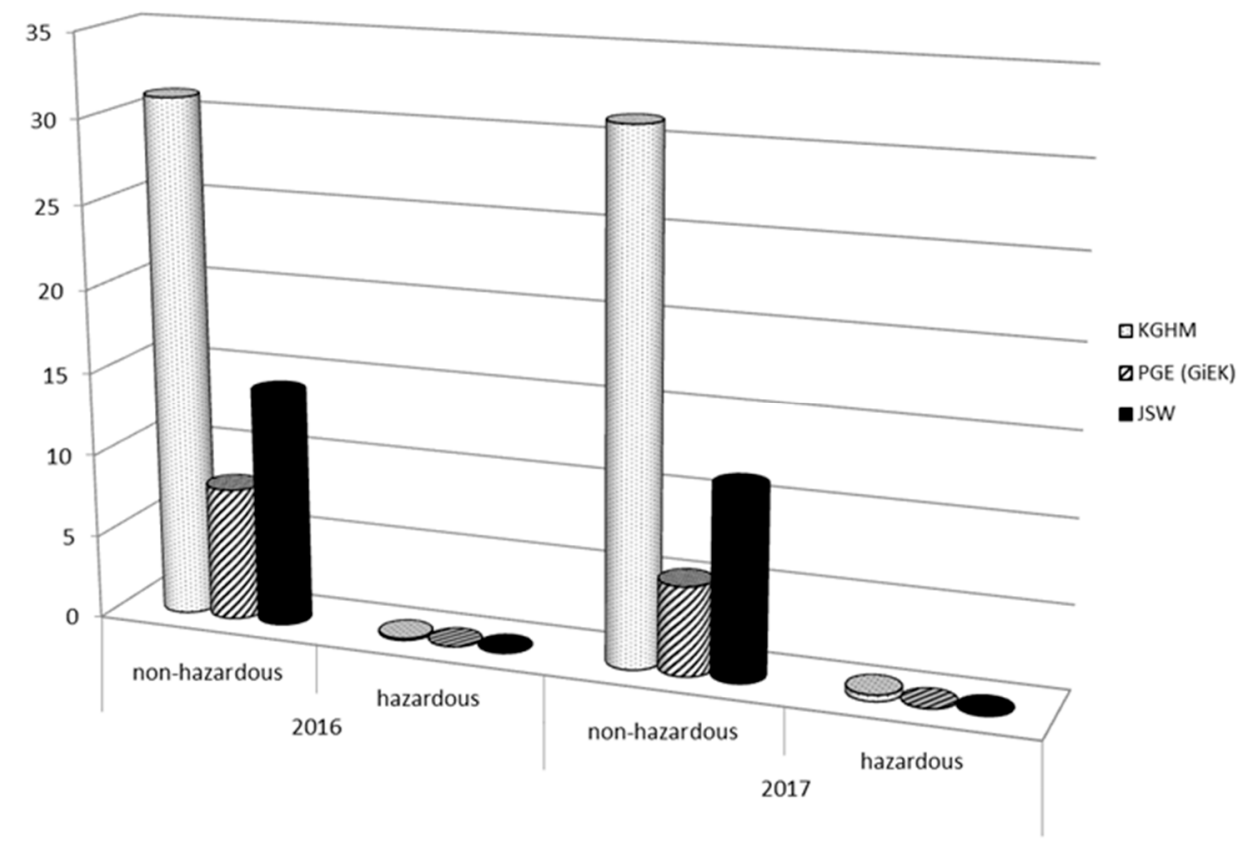

Figure 2. Total weight of waste utilized by KGHM and PGE (source: own study based on reports of KGHM, PGE, JSW [50-52]).

In the case of KGHM, non-hazardous waste (Figure 2) practically remained unchanged (a slight increase by $0.5 \%$ ), while in the case of two subsequent entities, it decreased (PGE GiEK by over $30 \%$, JSW by $20 \%$ ). Hazardous waste recorded an increase in the production, both in the case of KGHM (triple) and PGE (by nearly 30\%), while in JSW a decreased by over 30\% (for 2017 compared to 2016).

Disposal of mining waste created from the ore enrichment in KGHM is carried out in Obiekt Unieszkodliwiania Odpadów Wydobywczych (OUOW) Żelazny Most. This facility is being expanded and works are conducted aimed at improving the technology of waste storage. At the same time, safety is provided to the neighbouring communities of OUOW, while the KGHM PM Foundation finances trips for winter holidays and vacations to children from these areas. The company declares rational resource management and striving to maximum elimination of waste, as well as increase of managed 
waste in the general balance [50-52]. Moreover, KGHM along with the National Centre for Research and Development (pl. Narodowe Centrum Badań i Rozwoju) announced in 2018 a competition within which the applications proposing innovative solutions regarding the use of waste as secondary raw materials were accepted. 46 million PLN was intended for investments concerning the circular economy. One of the types of waste generated during the production at KGHM is granulated slag from an electric furnace at Copper Smelter Głogów II. The granulated slag is mainly used as: abradant in the shipbuilding industry, component of hydraulic backfill in mining, as well as for reclamation works. The highest consumption of granulated post-copper slag (approx. $50 \%$ ) is associated with backfilling works, constituting an alternative to natural sands. Also, the possibility of using slag as an aggregate in the construction and road building was confirmed [53]. The issue concerning the procedure in the scope of dealing with slag has recently become a problem reported by media. It concerns the so-called post-lead slag (waste from the production of raw lead) stored on the outskirts of Głogów and in Siemianowice Śląskie. It has become a source of conflict with the local community. It is sold by KGHM to Geran, which temporarily stores this waste in accordance with the law. At the stage of transport and storage, the slag requires protection in order to minimize the threat associated with dusting, which is harmful to people. This threat may also apply to water contamination. Media coverage of this issue is effective. The Provincial Inspector of Environmental Protection in Wrocław announced the control of the impact of stored waste on the environment. Similarly, the intervention was also carried out by the Inspector from Katowice. KGHM also demonstrated an interest in this waste [54].

At PGE, the waste is mainly generated in the process of combustion and in the processes of flue gas cleaning. The Group implements the following project: Installation of Thermal Waste Processing with Energy Recovery in the combined heat and power plant PGE in Rzeszów. The construction of this installation has been appreciated and PGE GiEK was awarded with "Nowy Impuls 2018" ("New Impulse 2018”) by the publisher of Magazyn Gospodarczy Nowy Przemysł and wnp.pl. The installation will burn approx. $100,000 \mathrm{Mg}$ of waste annually. Power of the new installation will cover $100 \%$ of demand of the Rzeszów's residents for heating water. GK PGE increases the level of use of the combustion by-products, searching for new applications for them. The purpose of activities carried out at PGE GiEK associated with the management of furnace waste created in the process of production of electricity and system heat is its use instead of natural resources. The Group promotes the use of raw materials from secondary sources, as well as material efficiency by implementing the "secondary first" principle, which allows to reverse the direction of conveyors with combustions by-products to the economy instead of the landfill. It uses raw materials from secondary sources in the infrastructural construction and cement industry [50-52].

In order to minimize the negative impact of generated waste on the environment and to increase revenues through rational management, JSW carries out activities conducive to: reducing the amount of generated waste, increasing the use of waste in underground mining excavations, sale of waste in unprocessed form, production and sale of aggregates produced from waste, waste management in waste management facilities on the surface. JSW uses mining waste and waste from the power plant, as well as salty water, among others for filling and sealing of abandoned workings of boulder walls or filling of closed excavations. According to the idea of CE, coal by-products is defined by JSW as raw materials that are not yet subject to use, but this is deemed a matter of time. While undertaking the implementation of activities compliant with CE, JSW signed a letter of intent with Haldex in 2017 relating to mutual cooperation in the scope of innovative methods of the mining waste management. This mainly concerns the waste after the process of coal refining: silt and flotoconcentrates. Another planned initiative is based on the use of Coal Tech's technology and the manufacture of pellets from coke, slits, dusts and coal waste. This would lead to obtaining fuel, liquidation of heaps, as well as development of the terrains created around the former Krupiński mine [50-52].

The mining waste produced by the presented companies KGM, PGE, JSW constitute the essence of the business strategy of the companies. Legal documents enforce greater awareness of waste producers of mining waste management. The presented activity is an example of this. 


\section{Conclusions}

Just like every industry, mining is subject to regulations, which enforce changes, particularly in terms of caring for the environmental or social sphere. Popularization of the issues of sustainable development, social and environmental responsibility or transparency of activities in the mining industry is becoming the pillar of changes.

Implementation and transfer of the rules and the idea of $C E$ is a specific challenge facing the mining industry. It must be considered that the specificity of mining enforces an individual approach also in this respect. The long-term goal of EU policy is to reduce the amount of generated waste, and if its generation is unavoidable, to promote their use as resources, wider dissemination of recycling and ensuring safe disposal of waste. Although the issues regarding sustainable management of mining waste appear in scientific works, this subject can be still regarded as current and worth attention [55]. The various manners of reusing waste from the mining industry as a raw material, among others in the construction, cement, agricultural sector or architectural processes and others, which are contained in this article, are very developmental. In the case of comparison of the position of Polish mining waste with other European countries, Poland can be perceived as a potentate in the development of CE in this field. As demonstrated in the article, this comparison cannot be carried out directly, due to differences in the classification of waste management at the levels of individual countries, including the share of mining as \% GDP is a more reliable measure. Domestic development directions should be seen mainly in the case of waste from in hard coal mining and preparatory works or waste from floatation dressing of nonferrous metal ores. The presented results indicate the need to search for new solutions in the scope of minimizing waste disposal by storing them. This problem concerns both municipal waste (in according with Swedish model) and the search for new solutions towards the management of mining waste, which most "mining economies" are struggling with. On the basis of the analysis of current situation in selected mining companies, it can be certainly concluded that companies are aware that the implementation of the CE assumptions is inevitable. All changes in this scope are associated with investments and expenses, however long-term benefits will be felt both in the environmental and social context. Changes in waste management of mining companies are gradual, as it is necessary to wait for the effects; the management of mining waste therefore constitutes a challenge on a local as well as global scale.

Author Contributions: The paper is a result of joint cooperation.

Funding: This scientific work was financed within Statute Research Studies (order 0401/0124/17 and 0401/0048/18).

Acknowledgments: We are grateful to anonymous reviewers for their comments on an earlier version of the manuscript, which for sure improved the clarity and quality of our manuscript.

Conflicts of Interest: The authors declare no conflict of interest.

\section{References}

1. COM/2014/398. Communication from the Commission to the European Parliament, the Council, the European Economic and Social Committee and the Committee of the Regions towards a Circular Economy: A Zero Waste Programme for Europe. Available online: https:/ / www.kowi.de/Portaldata/2/Resources / fp/2014-COM-circular-economy-annex.pdf (accessed on 1 October 2018).

2. Murray, A.; Skene, K.; Haynes, K. The Circular Economy: An Interdisciplinary Exploration of the Concept and Application in a Global Context. J. Bus. Ethics 2017, 140, 369. [CrossRef]

3. Smol, M.; Kulczycka, J.; Avdiushchenko, A. Circular economy indicators in relation to eco-innovation in European regions. Clean Technol. Environ. Policy 2017, 19, 669. [CrossRef]

4. Kirchherr, J.; Reike, D.; Hekkert, M. Conceptualizing the circular economy: An analysis of 114 definitions. Resour. Conserv. Recycl. 2017, 127, 221-232. [CrossRef]

5. Fang, Y.; Côté, R.P.; Qin, R. Industrial sustainability in China: Practice and prospects for eco-industrial development. J. Environ. Manag. 2007, 83, 315-328. [CrossRef] [PubMed] 
6. Sakr, D.; Baas, L.; El-Haggar, S.; Huisigh, D. Critical success and limiting factors for eco-industrial parks: Global trends and Egyptian context. J. Clean. Prod. 2011, 19, 1158-1169. [CrossRef]

7. Jackson, M.; Lederwasch, A.; Giurco, D. Transitions in theory and practice: Managing metals in the circular economy. Resources 2014, 3, 516-543. [CrossRef]

8. Pactwa, K.; Woźniak, J. Environmental reporting policy of the mining industry leaders in Poland. Resour. Policy 2017, 53, 201-207. [CrossRef]

9. Jarosiński, A.; Kulczycka, J. Ocena możliwości pozyskiwania niektórych surowców krytycznych w Polsce w związku z realizacją koncepcji gospodarki o obiegu zamkniętym. J. Pol. Miner. Eng. Soc. R. 2018, 19, 315-324. (In Polish)

10. Galos, K.; Szlugaj, J. Management of hard coal mining and processing wastes in Poland. Gospodarka Surowcami Mineral. Miner. Resour. Manag. 2014, 30, 51-64. [CrossRef]

11. EUROSTAT. Available online: http:/ / ec.europa.eu/eurostat (accessed on 20 August 2018).

12. Pilecka, E.; Morman, J. Wykorzystanie drobnoziarnistych odpadów wydobywczych wzmocnionych cementem do modernizacji obwałowań przeciwpowodziowych. Zeszyty Naukowe Instytutu Gospodarki Surowcami Mineral. Energia PAN 2017, 101, 347-359. (In Polish)

13. Rajczyk, K. Spoiwo mineralne uzyskane w wyniku prażenia odpadów flotacyjnych powstających w KGHM Polska Miedź S.A. Cement Wapno Beton 2017, 22, 239-249. (In Polish)

14. Klatka, S.; Malec, M.; Kruk, E.; Ryczek, M. Ocena możliwości przyrodniczego zagospodarowania odpadów powęglowych wykorzystywanych do niwelacji powierzchni. Acta Agroph. 2017, 24, 253-262. (In Polish)

15. Wróbel, J.; Fraś, A.; Przystaś, R.; Hycnar, J.; Tora, B. Uboczne produkty wzbogacania węgla źródłem paliw i kruszyw: Gospodarka odpadami poprodukcyjnymi w kopalniach Południowego Koncernu Węglowego SA. Inżynieria Mineral. 2017, 18, 39-45.

16. Lebre, E.; Corder, G.; Golev, A. The Role of the Mining Industry in a Circular Economy A Framework for Resource Management at the Mine Site Level. J. Ind. Ecol. 2017, 21, 662-672. [CrossRef]

17. Akbulut, H.; Gürer, C. Use of aggregates produced from marble quarry waste in asphalt pavements. Build. Environ. 2007, 42, 1921-1930.

18. Raupp-Pereira, F.; Ball, R.J.; Racha, J.; Labrincha, J.A.; Allen, G.C. New waste based clinker: Belite and lime formulations. Cem. Concr. Res. 2008, 38, 511-521. [CrossRef]

19. Torgal, F.P.; Castro-Gomes, J.P.; Jalali, S. Properties of tungsten mine waste geopolymeric binder. Constr. Build. Mater. 2008, 22, 1201-1211. [CrossRef]

20. Zhang, L.; Ahmari, S.; Zhang, J. Synthesis and characterization of fly ash modified mine tailings-based geopolymers. Constr. Build. Mater. 2011, 25, 3773-3781. [CrossRef]

21. Peralbo, C.R. Aplicaciones Técnico-Escultóricas de Hormigones y Morteros. Caracterización y Normalización (Technical-Sculpture Applications of Concretes and Mortars. Characterization and Standardization). Ph.D. Thesis, Department of Sculpture, University of Granada, Granada, Spain, 2007.

22. Kaźmierczak, U.; Blachowski, J.; Górniak-Zimroz, J.; Wirth, H. Quantitative and Qualitative Research on the Waste from the Mining of Rock Raw Materials in Lower Silesia. Minerals 2018, 8, 375. [CrossRef]

23. Castro-Gomes, J.P.; Silva, A.B.; Cano, R.P.; Suarez, J.D.; Albuquergue, A. Potencial for reuse of tungsten mining waste-rock in technical-artistic value added products. J. Clean. Prod. 2012, 25, 34-41. [CrossRef]

24. Bortone, I.; Chianese, S.; Erto, A.; Di Nardo, A.; Di Natale, M.; Santonastaso, G.F.; Musmarra, D. Risk analysis for a contaminated site in north of Naples (Italy). Chem. Eng. Trans. 2015, 43, 1927-1932.

25. Romaniuk, D.; Sorbjan, P.; Stefanek, P. Zastosowanie metody obserwacyjnej przy bezpiecznym wznoszeniu budowli geotechnicznych na przykładzie Obiektu Unieszkodliwiania Odpadów Wydobywczych Żelazny Most. Cuprum 2013, 1, 101-111. (In Polish)

26. O'Kelly, B.C. Sewage sludge to landfill: Some pertinent engineering properties. J. Air Waste Manag. Assoc. 2005, 55, 765-771. [CrossRef] [PubMed]

27. Anttonen, M.; Lammi, M.; Mykkanen, J.; Repo, P. Circular Economy in the Triple Helix of Innovation Systems. Sustainability 2018, 10, 2646. [CrossRef]

28. Directive 2014/95/EU of the European Parliament and of the Council of 22 October 2014 Amending Directive 2013/34/EU as Regards Disclosure of Non-Financial and Diversity Information by Certain Large Undertakings and Groups. Available online: https://eur-lex.europa.eu/legal-content/EN/TXT/PDF/?uri= CELEX:32014L0095\&from=en (accessed on 1 October 2018). 
29. ROZPORZĄDZENIE (WE) NR 2150/2002 PARLAMENTU EUROPEJSKIEGO I RADY z dnia 25 Listopada 2002 r. w Sprawie Statystyk Odpadów. Available online: https:/ / eur-lex.europa.eu/legal-content/PL/TXT/ PDF/?uri=CELEX:32002R2150\&from=EN (accessed on 13 August 2018).

30. ICMM. Role of Mining in National Economies (Romine). 2016. Available online: www.icmm.com/website/ publications/pdfs/social-and-economic-development/161026_icmm_romine-supplement_third-edition. pdf (accessed on 25 October 2018).

31. Pietrzyk, J.; Leoniewska-Gogola, J. Ocena zarządzania potencjałem surowcowym polskich gmin. In Proceedings of the International Conference on the Circular Economy-Rational Use of Raw Materials, Cracow, Poland, 18-19 September 2018.

32. Rajendran, K.; Bjork, H.; Taherzadeh, M.J. Borås, a Zero Waste City in Sweden. J. Dev. Manag. 2013, 1, 3-8.

33. Here's How Sweden Is Recycling 99\% of Its Waste by Garima Bakshi, 25 August 2016. Available online: https:/ / www.globalcitizen.org/ (accessed on 28 September 2018).

34. Finnveden, G.; Ekvall, T.; Arushanyan, Y.; Bisaillon, M.; Henriksson, G.; Gunnarsson Östling, U.; Ljunggren Söderman, M.; Sahlin, J.; Stenmarck, Å.; Sundberg, J.; et al. Policy Instruments towards a Sustainable Waste Management. Sustainability 2013, 5, 841-881. [CrossRef]

35. Swedish Waste Management 2017. Avfall Sverige. Available online: https://www.avfallsverige.se/ fileadmin/user_upload/Publikationer/Avfallshantering_2018_EN.pdf (accessed on 26 September 2018).

36. Statistics Sweden. Available online: http:/ / www.statistikdatabasen.scb.se/ (accessed on 27 September 2018).

37. Quality Report on Waste Statistics 2014 Generation of Waste and Recovery and Disposal of Waste according to EU Regulation on Waste Statistics Sweden. Available online: https: / / www.naturvardsverket.se (accessed on 27 September 2018).

38. Johansson, N.; Corvellec, H. Waste policies gone soft: An analysis of European and Swedish waste prevention plans. Waste Manag. 2018, 77, 322-332. [CrossRef] [PubMed]

39. Dz U. 2017.1849 USTAWA z dnia 10 lipca 2008 r. o Odpadach Wydobywczych. Available online: http:// geoportal.pgi.gov.pl/css/powiaty/2018/ustawy/7_odpady_wydobywcze.pdf (accessed on 13 August 2018).

40. Ptak, M.; Kasztelewicz, Z. Nowe rozwiązania w zakresie gospodarowania odpadami wydobywczymi. Min. Sci. 2013, 43, 185-194. (In Polish)

41. Available online: http://stat.gov.pl/obszary-tematyczne/srodowisko-energia/srodowisko/ochronasrodowiska-2017,1,18.html (accessed on 10 October 2018).

42. Fajfer, J.; Krieger, W.; Rolka, M.; Antolak, O. Opracowanie Metodyki Wykonania Spisu Zamkniętych Obiektów Unieszkodliwiania Odpadówwydobywczych Oraz Opuszczonych Obiektów Unieszkodliwiania Odpadów Wydobywczych, Które Wywierają Negatywny Wpływ Na Środowisko; PIG-PIB: Warszawa, Poland, 2010.

43. Grabas, K.; Pawlik, A. Examination of the durability of bitumen layer/coating that prevents dusting of flotation tailings pond “Żelazny Most”. Górnictwo Odkrywkowe 2017, 58, 29-35.

44. Rajczyk, K. Spoiwo mineralne oparte na przetworzonych termicznie odpadach flotacyjnych powstających w KGHM Polska Miedź S.A. Prace Instytutu Ceram. Mater. Budowlanych Rocznik 2016, 9, 71-83.

45. Rajczyk, K. Opracowanie Spoiwa Mineralnego w Oparciu o Przetworzone Termicznie Odpady Flotacyjne Powstające w KGHM Polska Miedź S.A., Instytut Szkła, Ceramiki, Materiałów Ogniotrwałych i Budowlanych, Oddział Inżynierii Materiałowej, Procesowej i Środowiska, Opole 2009 (9/460/P). (Scientific Works in Polish). Available online: http:/ /icimb.pl/opole/images/stories/PDF/prace_icimb_nr_27_art_7. pdf (accessed on 10 October 2018).

46. Program dla Sektora Górnictwa Wegla Kamiennego w Polsce, Ministerstwo Energii Warszawa. 2018. Available online: https://www.gov.pl/documents/33372/436746/Program_dla_sektora_górnictwa_węgla_ kamiennego_w_Polsce.pdf/4cd0f128-45a8-0f98-c4e0-c763d0f1754d (accessed on 24 October 2018).

47. Drenda, J.; Różański, Z.; Słota, K.; Wrona, P. Zagrożenia pożarowe na składowiskach odpadów powęglowych. Górnictwo i Geoinżynieria 2007, 31, 149-157. (In Polish)

48. Gogola, K.; Bajerski, A.; Smoliński, A. Modyfikacja metody oceny zagrożenia pożarowego na terenach lokowania odpadów poweglowych. Pace Naukowe GIG Górnictwo Środowisko 2012, 2, 13-31. (In Polish)

49. Błażej, R.; Jurdziak, L.; Kozłowski, T.; Kirjanów, A. The use of magnetic sensors in monitoring the condition of the core in steelcord conveyor belts-Tests of the measuring probe and the design of theDiagBelt system. Measurement 2018, 123, 48-53. [CrossRef]

50. Reports CSR. KGH. Available online: https:// kghm.com/pl (accessed on 3 September 2018).

51. Reports CSR. JSW. Available online: https://www.jsw.pl/ (accessed on 3 September 2018). 
52. Reports CSR. PGE. Available online: https://www.gkpge.pl (accessed on 3 September 2018).

53. Duszyński, A.; Jasiński, W.; Pryga-Szulc, A. Ocena i wykorzystanie kruszywa z pomiedziowego żużla granulowanego do mieszanek gruntowo-kruszywowych. Biuletyn Państwowego Instytutu Geol. 2017, 469, 85-92. [CrossRef]

54. Journal Website. Available online: http:/ / www.gazetaprawna.pl (accessed on 28 September 2018).

55. Aznar-Sánchez, J.A.; García-Gómez, J.J.; Velasco-Muñoz, J.F.; Carretero-Gómez, A. Mining Waste and Its Sustainable Management: Advances in Worldwide Research. Minerals 2018, 8, 284. [CrossRef]

(C) 2018 by the authors. Licensee MDPI, Basel, Switzerland. This article is an open access article distributed under the terms and conditions of the Creative Commons Attribution (CC BY) license (http:/ / creativecommons.org/licenses/by/4.0/). 